Artiom Mesheznikov, Safarali Shomakhmadov

\title{
The Updated Data on Sanskrit Manuscripts of the Serindia Collection (IOM, RAS): Perspectives of the Study
}

DOI 10.17816/wmo56800

Abstract: This article presents the preliminary results of the study on the Sanskrit manuscripts of the Serindia Collection of the Institute of Oriental Manuscripts, RAS. Basing on the previous researches, as well as on the results of the efforts of the 'Sanskrit Group' within Serindica Laboratory, the authors outline the structure and repertoire of the Sanskrit part of the Serindia Collection, supplementing it with the description of paleographic and codicological aspects of the Sanskrit manuscripts.

Key words: paleography, Brāhmī, Sanskrit manuscripts, Tarim oases, Serindia manuscripts Collection

The penetration of Buddhism into Central Asia dates back to the first centuries of the 1st millennium $\mathrm{AD}$ and is associated with India. ${ }^{1}$ However, it is not clear yet how Buddhism spread and developed in this region and what features this Indian religion had while its expanded inside the Tarim Basin (these territories are also known as Serindia and East [Chinese] Turkestan; at present Xinjiang Uyghur Autonomous Region of PRC). Basing on the paleographical research of manuscripts that have been preserved to nowadays, we can assume that Sanskrit was used as the main language of the transmission of the Buddhist tradition in the first centuries AD. Later, when Buddhist texts were translated into the local Central Asian languages, Sanskrit was used as a language of the Central Asian Buddhist written tradition.

(C) Artiom Vladimirovich Mesheznikov, Institute of Oriental Manuscripts, Russian Academy of Sciences (mesheznikoff@yandex.ru)

(C) Safarali Haibulloevich Shomakhmadov, Institute of Oriental Manuscripts, Russian Academy of Sciences (safaralihshom@mail.ru)

${ }^{1}$ Vostochnyi Turkestan 1992: 115. 


\section{Provenance and History of Study}

The Serindia manuscripts Collection perhaps is the most multilingual and 'multi-scriptual' among all the manuscript collections of the St. Petersburg Institute of Oriental Manuscripts of the Russian Academy Sciences (IOM, RAS). It is very heterogeneous in terms of genres and functional purposes of the texts. A significant part of the Serindian Manuscripts Collection are Buddhist manuscripts in Sanskrit.

The St. Petersburg collection of Sanskrit manuscripts from the Tarim Basin oases consists mainly of the items that were obtained thanks to the efforts of the Russian consuls and diplomats in East Turkestan: the Consul-General in Kashgar Nikolai F. Petrovskii (1837-1908), Consul General in Urumqi Nikolai N. Krotkov (1869-1919), secretary of the consulate in Kashgar Mikhail I. Lavrov (1877-1934), doctor of the Russian consulate in Urumqi Aleksandr I. Kokhanovskii and others. The key role in this process belongs to Nikolai F. Petrovskii. Since 1867 he collected manuscripts and objects of Buddhist art and in every possible way contributed to the comprehensive research of the Serindia region. Through his activities he initiated a wide study of the Indian written heritage in Central Asia. ${ }^{2}$

The first publisher of the Central Asian Sanskrit manuscripts kept in the Asiatic Museum was the academician Sergei F. Oldenburg (1863-1934), who conducted the identification of the Central Asian scripts and miscellaneous texts contained in the discovered manuscripts. ${ }^{3}$ He and Andrei I. Vostrikov (1902-1937) prepared an inventory of the collection, where 240 items were listed. $^{4}$

Manuscripts sent by Nikolai F. Petrovskii to Sergei F. Oldenburg during 1893-1903 were published in ZVORAO. ${ }^{5}$ In addition to the facsimiles and the transliteration these publications contain the academically founded identification of the texts, preliminary paleographic and codicological information. Sergei F. Oldenburg also planned to publish all Sanskrit manuscripts and fragments from East Turkestan in a separate special series. Thus, Irina V. Tunkina had found the Oldenburg transliterations of the Sanskrit manuscripts in the collection of acad. Fiodor I. Scherbatskoi in the St. Petersburg Branch of the Archive of the RAS. The typographic proof of the

\footnotetext{
${ }^{2}$ Peshchery tysiachi Bidd 2008: 29.

${ }^{3}$ Pamiatniki indiiskoi pis'mennosti 2004: 26.

${ }^{4}$ Inventory No. 1: 1930.

${ }^{5}$ Ol'Denburg 1893, 1899, 1904.
} 
4th part and the draft plan of the 5th part of the series of articles entitled "The Fragments of Kashgar Sanskrit Manuscripts from the Collection of Nikolai F. Petrovskii" were found in the same collection. ${ }^{6}$

A. Staël von Holstein (1877-1937) and Nikolai D. Mironov (1880-1936), the colleagues of Sergei F. Oldenburg, continued the research of Sanskrit manuscripts and fragments from the St. Petersburg Collection. Staël von Holstein had published the transliteration of Kāśyapaparivarta-sūtra (SI 1905), as well as one Tibetan and four Chinese translations of this text. ${ }^{7}$ Mironov had published the bilingual fragment of Dharmapada in Sanskrit and Tocharian B. ${ }^{8}$

In the $1950 \mathrm{~s}$, after a long 'time-out' caused by the period of repressions (1930s) and the World War II, the new stage of the research of the Serindia manuscripts heritage was began by a young talented scholar Vladimir S. Vorobiov-Desiatovskii (1927-1956). He investigated Sanskrit, Khotanese and Tibetan manuscripts, ${ }^{9}$ published folios of the Kāśyapaparivarta sūtra manuscript (SI 1905), syllabic tables of the South Turkestan and North Turkestan Brāhmī (SI 1039, SI 1040, SI 1909, SI 3120), fragments of the Sanskrit explanatory dictionary and Sanskrit-Tocharian bilingual text (SI 2042, SI 2042). ${ }^{10}$ Unfortunately, Vorobiov-Desiatovskii had an ill heart and passed away when he was just 29.

The new academic team, acad. Grigorii M. Bongard-Levin (1933-2008), Eduard N. Tiomkin (1928-2019), Margarita I. Vorobiova-Desiatovskaia (born in 1933), continued the pursue of Vladimir S. Vorobiov-Desiatovskii. They had introduced into academic circulation the numerous Sanskrit manuscripts of Serindia Collection (former Central Asian Collection). The result of their efforts was the publishing of three volumes of "The Monuments of Indian Writing from Central Asia” (1985, 1990 and 2004). The research of this academic group has reached a new level: the publications were provided with facsimiles, transliterations, translations and comments on the Buddhist texts that these manuscripts contain. Many ZVORAO articles of Sergei F. Oldenburg were republished by Bongard-Levin, Tiomkin and Vorobiova-Desiatovskaia in the above-mentioned editions. The innovations included the addition of new call numbers of the manuscripts, new codicological data, comments and the transliteration according to international standards.

\footnotetext{
${ }^{6}$ SHOMAKHMAdOV 2016.

${ }^{7}$ STAËL-Holstein 1926.

${ }^{8}$ Mironov 1909.

${ }^{9}$ Ibid.

${ }^{10}$ Vorobiov-Desiatovskil 1957, 1958
} 
In addition to the above-mentioned works, Bongard-Levin and Tiomkin and Vorobiova-Desiatovskaia published articles devoted to previously unknown Sanskrit manuscripts from East Turkestan. ${ }^{11}$ Some manuscripts were published in collaboration with the Japanese and German scholars. ${ }^{12}$

Since 2010s Safarali H. Shomakhmadov has continued the research of Sanskrit manuscripts of Serindia Collection. Besides the articles written in collaboration with Margarita I. Vorobiova-Desiatovskaia, ${ }^{13}$ he had published some papers devoted to two Tangut block prints (SI 6563, SI 6564) containing Sanskrit dhārạ̣̄ written in Siddham script. ${ }^{14}$

Foreign scholars also did extensive research of the Sanskrit manuscripts from the Serindia Collection, both in cooperation with IOM colleagues and independently. Japanese researcher Hirofumi Toda wrote a comprehensive monograph devoted to the study of Lotus Sutra ${ }^{15}$ that contains transliteration of the Central Asian version of the sutra accompanied with parallel passages of the all known Lotus Sūtra manuscripts from the European and Asian manuscripts collections (including the ones kept in Russia). ${ }^{16}$ In particular, Hirofumi Toda's monograph contains transliterations of two manuscripts from the Serindia collection: the fragment of Lotus Sutra (SI 2077) and so-called 'Nikolai F. Petrovsky Kashgar manuscript' (SI 1925, SI 1927). The last one is the most complete Central Asian version of Saddharmapuṇụiaika-sūtra.

The German scholar Oskar von Hinüber (born in 1939) also had researched the Lotus Sütra manuscripts from Serindia collection: he had published the transliteration and the detailed research of the colophons of some Lotus Sutra manuscripts from the Serindia Collection including 'Nikolai F. Petrovskii Kashgar manuscript' (SI 1925, 1927). ${ }^{17}$

${ }^{11}$ Bongard-Levin 1972, 1975a, 1975b, 1977, 1979, 1980, 1981, 1982, 1989, 1994; BonGard-Levin \& Vorobiova-Desiatovskaia \& Tiomkin 1967; Bongard-Levin \& Tiomkin 1968; Bongard-Levin \& Vorobiova-Desiatovskaia 1986, 1987; Tiomkin 1995a, 1995b, 1996; Vorobiova-Desiatovskaia \& Tiomkin 1998, 2000; Vorobiova-Desiatovskaia 1995; VorobiovaDesiatovSKaIA 1999-2002.

12 Bongard-Levin \& Kimura 1995; Bongard-Levin \& Boucher \& Fukita \& Wille 1996; Bongard-Levin \& Hori 1996; Bongard-Levin \& Watanabe 1997; Vorobiova-Desiatovskaia \& Karashima \& Kudo 2002; Karashima, Vorobiova-Desiatovskaia 2007, 2008; Kudo \& VoROBIOVA-DESIATOVSKAIA 2007.

${ }^{13}$ Vorobiova-Desiatovskaia, Shomakhmadov 2010, 2011, 2013.

${ }^{14}$ Shomakhmadov 2014, 2016, 2017.

15 TODA 1981.

16 Vorobiova-Desiatovskaia 2004, 206.

${ }^{17}$ HINÜBER 2015. 
Japanese scholars Seishi Karashima, Tatsushi Tamai from the International Research Institute of Advanced Buddhology and their colleagues made an important contribution in the methodology of the Sanskrit Buddhist manuscripts research. The result of close collaboration of the international research group headed by Karashima and St. Petersburg scholars resulted in the publication of the first volume of 'The St. Petersburg Sanskrit Fragments'. ${ }^{18}$ This collective monograph contains re-editions of the follows manuscripts from the Serindia Collection: Śārdūlakarṇāvadāna (SI 1942, SI 3431, SI 5145), Ajitasenavyākaraṇa (SI 2085), Mahāparinirvāṇa-sūtra (SI 3038, SI 3042) and the part of Merv manuscript (SI 6580).

Among the articles devoted to the St. Petersburg manuscripts and published by international researchers it is necessary to mention the publication by Shin'ichirō Hori, dedicated to the Kalpanāmaṇịitikā fragments (SI 2041/5, SI 3695) written in the so-called Gilgit-Bamiyan Brāhmī (Type II) script ${ }^{19}$ as well as the paper of German scholar Klaus Wille, who published the Buddhanāma-sūtra fragments (SI 3457, SI 3458, SI 3467). ${ }^{20}$

Despite of the great number of articles of Russian and foreign researchers devoted to the study of Central Asian written heritage from the Serindia Collection kept in IOM, RAS, the main part of these manuscripts needs the more detailed research.

\section{A General Survey of the Sanskrit Manuscripts from the Serindia Collection}

The Sanskrit collection stands out among all the other holdings of the Serindia Collection due to its abundance and multeity. All kinds of material for the manuscripts, different script types and styles are presented in this collection. It is necessary to stress out the variety of contents of the Buddhist Sanskrit manuscripts: many texts belong to different historical periods and originate in the different Buddhist sects and Buddhist literature genres.

The number of all the inventoried Sanskrit manuscripts in the Serindia Collection kept within various sub-collections is about 700 items. ${ }^{21}$ Most of the Sanskrit manuscripts belong to the Petrovskii collection (464 items).

\footnotetext{
18 Karashima \& Vorobiova-Desiatovskaia 2015.

${ }^{19}$ HORI 2011.

${ }^{20}$ WolLE 1997-1998.

${ }^{21}$ Some manuscripts need detailed research.
} 
Berezovskii collection is represented by 73 storage items, Oldenburg collection - 56, Krotkov collection - 42, Lavrov collection - 38, Malov collection - 10, Klementz collection - 3, Kolokolov collection - 3, Kozlov collection - 2. The Kokhanovskii and Likhachev collections have one item each. 7 items do not belong to any collection.

The identified Sanskrit manuscripts from the Serindia collection, perhaps, present all the main Buddhist canonical literature genres of both Hinayāna and Mahāyāna: Prajñāpāramitā texts, Vinaya fragments, Abhidharma treatises, Jātakas, Dhāraṇī. The latter was very popular among Serindian Buddhists. Up to date the overwhelming majority of the Buddhist Sanskrit texts (508 items) have not been identified, some of the fragments do not correspond to any known Buddhist Sanskrit text.

\section{Materials}

The analysis of the materials of the Sanskrit manuscripts allows to research the manuscript culture in Serindia particularly and in Central Asia in whole. The paper production in the Tarim oases had caused the active growth of the recording of Buddhist texts in local paper and neutralized the need to import Buddhist texts from India and China directly. In its turn, it had caused the formation of own Central Asian manuscript culture. It's notable that the Buddhism reception within Serindia was reflected in the change of the manuscripts materials, the scripts development and the genre transformation of Buddhist literature.

Palm leaf is the earliest material of Buddhist manuscripts in Central Asia. Apparently, this is the case of Buddhist manuscripts import directly from India to the Tarim oases. This assumption is confirmed by the fact that the script of the Serindia Sanskrit texts written on palm leaf is either the Kușāna Brāhmī (2th-3th cc.), or the North-Western (Indian) Gupta (4th-6th cc.). ${ }^{22}$ The Sanskrit manuscripts fragments on palm leaves in Brāhmī script kept in the Turfan collection in Berlin and in the Serindia Collection in St. Petersburg are most ancient. $^{23}$

\footnotetext{
${ }^{22}$ Hereinafter, we use the chronology established by the German specialist in Central Asian paleography Lore Sander. This classification, in our opinion, in a best way reflects the process of the Buddhism reception in Serindia (SANDER 2005).

${ }^{23}$ The written fixation of religious texts in India began in the first centuries AD. The texts written on palm leaf in the Kuṣanna Brāhmī reflect the earliest stage in the development of Indian Buddhist manuscript culture.
} 
The 'Sanskrit division' of the Serindia Collection includes 20 manuscripts on palm leaf. The fragments of canonical Abhidharma - the philosophical level of Buddhist doctrine - have an undoubted interest for the detailed research. Two of them (2th-3th cc.) written in the Kusānạa Brāhmī ('Spitzer Manuscript' SI 1424-142524 are the oldest Sanskrit fragments from the Serindia Collection. Another two fragments (4th-5th cc.) on palm leaf (SI 14261427) containing Abhidharma texts were written in the Indian Gupta script. Other palm-leaf manuscripts are small fragments containing few akșaras only. They can be used to identify the script type and an approximate dating, but it is not possible to identify the texts.

The Serindia Manuscripts Collection contains about 90 Sanskrit fragments on birch bark written in Indian script types, as well as in Central Asian ones the Turkestan Gupta (4th-5th cc.) and the southern variety of the Early Turkestan Brāhmī (5th-6th cc.). ${ }^{25}$ Regarding the birch bark manuscripts from the Serindia Collection we can see that, as a rule, the upper thin translucent layers were used for making a leaf of the manuscript which were then glued or pressed. ${ }^{26}$ The manuscripts containing the fragments of Vinaya (SI 1943) and Abhidharma (SI 6583) are rare examples of identified birch bark manuscripts. Most of the items are pieces of poorly preserved birch bark manuscript fragments containing only separate words without any chance to identify the text content. $^{27}$

${ }^{24}$ Franco 2004; BROCKINGTON 2010.

${ }^{25}$ Birch bark manuscripts were also imported to the centers of Buddhist culture in Serindia from the regions of North India and Kashmir where this material was typical for the manuscript tradition (Vorobiova-Desiatovskaia 1988a: 27). The use of the local, Central Asian, script types indicates that not only birch bark manuscripts were imported from India but also birch bark itself as a material for manuscripts.

${ }^{26}$ Vorobiova-DesiatovsKaia 1988a: 28.

27 The most representative example of birch bark manuscripts from the Serindia Collection is the mentioned above Merv manuscript (SI 6580). The manuscript numbers about 160 leaves; the text was written in Indian Gupta (4th-5th cc.). This manuscript contains fragments of Sarvāstivāda Vinaya, various passages from sūtras, avadānas and jātakas that makes possible to reconstruct the Sarvāstivāda Sanskrit Buddhist canon. The manuscript text is, apparently, a synopsis for a Buddhist preacher. This fact, in turn, provides material for the study of the key subjects of the Buddhist narrative and the code of the monastic community that were the most representative in the spread of Buddhism in non-endemic zones during the 4th-5th cc. Taking into account the place of this artifact find, we can contradict that this manuscript doesn't belong to Serindia manuscript culture directly. However, typologically, it fully fits into the framework of the manuscript culture of the Central Asian region. In terms of the totality of codicological and paleographic features, as well as in content, the Merv manuscript is very similar to the manuscripts discovered in the Tarim oases. 
Buddhist manuscripts fragments on paper are largest manuscripts collection in the 'Sanskrit division' of the Serindia Collection. ${ }^{28}$ The vast majority of Dhāraṇi texts, ${ }^{29}$ all versions of Mahāyāna texts: Saddharmapuṇụarīka sūtra, Prajñāparamitā-sūtra, Mahāparinirvāṇa-sūtra and Kāśyapaparivarta-sūtra are written on paper. This group includes two large avadānas — Śārdūlakarṇāvadāna and Ajitasenavyākaraṇa — and many other manuscripts of the Serindia Collection. The paper spread within Serindia had coincided with the appearance of first translations of Buddhist texts into local languages. ${ }^{30}$ The Central Asian Brāhmī based on Indian scripts was adapted for the writing Buddhist texts in local East Turkestan languages. The process of Brāhmī scripts adapting in the Northern and Southern Tarim oases had led to certain changes in the Central Asian manuscript culture. As a result, since 4th till 10th cc. some manuscript traditions were formed as well as many local scripts had appeared. Those 'new scripts' were used for write Buddhist texts both in Sanskrit and in local languages.

\section{Scripts}

Only a few little fragments on palm leaves and birch bark from the 'Sanskrit division' of the Serindia Collection were written in Kuṣāna Brāhmī script. The codicological description of these manuscripts is complicated by the severe damage of the items. Only two paginated leaves have survived — the 'Spitzer manuscript' fragments (SI 1424-25) that have a pagination on the left side of the obverse. The margins are narrow, not graphically delineated. The binding hole on the left side of the leaf doesn't mark decoratively. There are no guidelines. The approximate size of the sheet is $4 \times 20 \mathrm{~cm}$.

The manuscripts written in Indian Gupta script (4th-6th cc.) are more numerous. This script type was used in manuscripts on palm leaves (Abhid-

\footnotetext{
${ }^{28}$ Vorobiova-Desiatovskaia notes that paper production in the Tarim oases (namely, in Kashgar and Khotan) began a bit later than in China - in the 2-3rd cc. The mechanically crushed bark of Paper Mulberry (Broussoneria papyrifera) was used for a paper production (Vorobiova-Desiatovskaia 1988b: 333). Later, in the 4th c. a paper production was spread in Turfan and Kucha (HoERnLe 1902: 13).

${ }^{29}$ Exept dhāran̄i on wooden tablets (SI 6586).

${ }^{30}$ At the same time, Sanskrit was remaining the Buddhist scholarship language. The key Buddhist texts were not translating into local languages and was functioning in Sanskrit but accompanying by comments into local languages.
} 
harma fragments, SI 1426-27), on birch bark (Vinaya fragments SI 1943; Abhidharma fragments SI 6583) and on paper (Śārdūlakarnāavadāna, SI 1942). Pagination occurs both on recto (SI 1942) and verso (SI 2038, SI 6580). The fields are narrow $(0.6 \mathrm{~cm})$ and not marked graphically. There is a hole for binding on the left side of a leaf that is not graphically marked any way. ${ }^{31}$ Guidelines are not visible, nevertheless, a fairly high level of calligraphy is observed, the lines are even (in SI 1942 and SI 2038 the distance between lines is $0.8-0.9 \mathrm{~cm}$ ) ${ }^{32}$ Woven paper, good quality (paper pulp is even, equally shredded), there are traces of a primer. ${ }^{33}$ Manuscripts on palm leaf and paper are single-layer while birch bark manuscripts are glued together from two layers. The average size of this type of manuscript is $5 \times 22 \mathrm{~cm}$ (on a palm leaf), $5 \times 19 \mathrm{~cm}$ (on birch bark) and $7 \times 18 \mathrm{~cm}$ (on paper).

About forty Sanskrit manuscripts written in Turkestan Gupta script (4th5th cc.) in the period before the division into Northern (Tocharian) and Southern (Khotanese) Brāhmī varieties are the special paleographic interest: Turkestan Gupta script has the characteristic features of both scripts. Manuscripts of this type are presented mainly on paper (except of small pieces of birch bark and poorly preserved wooden tablets). ${ }^{34}$ Fragments of Vajrapānihịndaya (SI 2034), Mahāsāhasrapramardin̄̄ (SI 2040/1-2), Aniruddha-sūtra (SI 3031), and a manuscript that content is defined as an 'spell' (SI 2025) are examples of manuscripts written in this script. Pagination, like in the previous script case, occurs both on recto (SI 3031) and verso (SI 2025). Margins and hole for

${ }^{31}$ The binding hole in the Merv manuscript is located very close to the left edge (approx. $2 \mathrm{~cm}$ ). In other manuscripts the hole is located much further - approx. at the border of the first and second quarter of the leaf.

32 Because of the lines in the manuscripts written on paper in Indian Gupta script are very clear and accurate it can be assumed that the guidelines were presented. The manuscripts guidelines on palm leaf and birch bark were no need because of natural features of these materials (streaks of palm leaf and 'stripes' of birch bark) were used as a 'natural lines'. The Central Asian manuscripts had, as a rule, color guidelines made by red or black pigment. Sometimes guidelines were colorless made by squeezing a groove on the leaf by a lead stick (VoroBIovaDesiatovskaia 1988b: 337).

${ }^{33}$ During the Sanskrit manuscripts checking some paper variants were encountered. It could be laid, woven or without any trace of guidelines. The paper pulp was either perfectly shredded or with small pieces of non-ground fiber, or large pieces of fiber visible to the naked eye (for more information see: DURKIN-MeISTERERnST 2016).

${ }^{34}$ The fragments on wooden tablets are splinters placed in the Melinex cover (SI 2959, SI 3424 , SI 3428). 
binding are not graphically marked. ${ }^{35}$ The laid paper of good quality. Guidelines are not visible, however, equal distances between the lines $(0.9-1 \mathrm{~cm})$ are observed. Leaves have different sizes, there are both medium $(7 \times 20 \mathrm{~cm}$, SI 2024) and large $(8 \times 30 \mathrm{~cm}$, SI 3031$)$.

It's necessary to mention separately the manuscript written in Turkestan Gupta in a scroll format (SI 2040/1-2) ${ }^{36}$ that is unique for the Sanskrit division of the Serindia Collection. The size of the one manuscript fragment is $12.5 \times 7.5 \mathrm{~cm}$, the second $-57 \times 7.5 \mathrm{~cm}$. The woven paper of good quality. There are no guidelines, the distance between the lines is $1-1.2 \mathrm{~cm}$. The margins are narrow, about $0.5 \mathrm{~cm} .{ }^{37}$

Examples of Northern Brāhmī varieties in the Serindia Collection are extremely few in comparison with Southern Brāhmī scripts caused by the history of expeditions to East Turkestan organized by Russian and foreign researchers in the late 19th - early 20th cc. However, the available manuscripts from the Northern oases of Tarim basin allow us to trace the evolution of the Brāhmī script in the north of Serindia. Thus, some items in the collection represent the Early Turkestan Brāhmī (type I, 5th-6th cc.) - the script of Sanskrit manuscripts compiled in the Northern oases of the Tarim basin (SI 2027, SI 2035, SI 2045, SI 2069-70). There are no guidelines in these manuscripts; the binding hole is not specially marked. The primed paper, sometimes woven (SI 2027) and laid (SI 2070). The approximate leaf size is $6 \times 21 \mathrm{~cm}$.

The manuscripts written in Northern Turkestan Brāhmī developed from Early Turkestan Brāhmī (type 1) and spread in northern Serindia oases in 7th-9th cc. are presented more widely in the 'Sanskrit division' of the Serindia Collection. Prātimokșa-sūtra (SI 964-971), the syllable tables (SI 10381040), Śārdūlakarṇāvadāna (SI 3431, SI 5145), Māṇibhadra-dhāraṇī (SI 2036, SI 2041/1), Dhāraṇī (SI 2037), Nagaropama-sūtra (SI 2041/3, SI 2041/6), Pārājikadharma fragment (SI 2041/7), etc. are among the manuscripts written by this script type. In contrast with mentioned above script types with unstable pagination the pagination in the manuscripts written in Northern Turkestan Brāhmī is placed strictly on verso. The manuscripts written in this script type have guidelines made by red ink (SI 2041/3, SI 2041/6-7, SI 5145) and brown

\footnotetext{
${ }^{35}$ In the case of the SI 2034 it can be noted that a blank area without text was on the leaf for the binding hole space while for another manuscript the hole was simply located between the lines, taking up only a small amount of space.

${ }^{36}$ All another Sanskrit manuscripts have the pothi format only.

${ }^{37}$ Perhaps such unusual shape of this manuscript can be explained by the fact that this scroll with a spell text was made as an amulet.
} 
one (SI 1040). ${ }^{38}$ The one more peculiarity inherent in the manuscripts written in Northern Turkestan Brāhmī is the graphical marking both left and right margins: the leaves of the manuscript SI 5145 have traces of marking - both margins are outlined in red ink. The paper of high quality, some places with perfectly shredded paper pulp without any visible fiber fragments, laid (SI 964-971) or without laid traces (SI 1040), in some cases primed (SI 964-971, SI 2041/6, SI 5145). There is usually a rectangular space marked by guidelines around the binding hole. The standard leaf size is $5 \times 20 \mathrm{~cm}$ (SI 964-965, SI 2041/3). However, there is also a large format $(8 \times 55 \mathrm{~cm}$, SI 5145$)$. Thus, the peculiar tradition of the manuscripts decoration developed in the northern Tarim oases: the pagination strictly on verso, the required guidelines, the marking of the margins and the rectangular area for binding hold are specific features of the Northern Turkestan manuscripts.

The manuscripts from the Southern oases of Tarim basin (Khotan, Niya, Endere) are the most representative and numerous among all Sanskrit manuscripts of the Serindia Collection. According to L. Sander classification, the southern group of Brāhmī varieties is represented by four successive script types: Early Turkestan Brāhmī (type 2, 5th-6th cc.), Early Southern Turkestan Brāhmī (7th-8th cc.), Southern Turkestan Brāhmī (8th-9th cc.), Later Southern Turkestan Brāhmī (9th-10th cc.). The manuscripts written in Early Turkestan Brāhmī (type 2) and Southern Turkestan Brāhmī are most numerous among the manuscripts discovered in the southern Tarim oases because of that, obviously, they correspond to the periods of Buddhism flower in Khotan. The examples of Later Southern Turkestan Brāhmī are very few and characterized by somewhat artsy calligraphy.

The fragments of Mahāparinirvāṇa-sūtra (SI 3038, SI 3042, SI 3043), numerous fragments of Prajñāpāramitā texts (SI 2016-2019, SI 3032-3033, SI 3685, SI 3687), Saddharmapuṇuarīka-sūtra (SI 3030, SI 3330, SI 3332/3), Suvarnabhāsottama-sūtra (SI 3329/1-3), Kāśyapaparivarta-sūtra (SI 3037), Prātimokșa-sūtra (SI 3332/1), etc. are examples of the manuscripts written in Early Turkestan Brāhmī (type 2). The Serindia Collection contains the Sanskrit manuscripts (in pothī format) written in this script type that have a huge size. There are manuscripts fragments of non-standard size (SI 2017, SI 2019). ${ }^{39}$

\footnotetext{
38 The red ink guidelines are inherent in the manuscripts written in Northern Turkestan Brāhmī only (among the Sanskrit manuscripts of the Serindia Collection).

${ }^{39}$ For more details see: BongARD-LEVIN \& HorI 1996
} 
Thus, the size of a whole leaf of the manuscript was approximately $25 \times 60 \mathrm{~cm}$ that obviously exceeds the standard size. To prepare leaves of such large size they were glued together in two parts. This is confirmed by the gluing stripes preserved in the central part of the fragment SI 2017 and on the right side of the fragment SI 2019.

The colored miniature (the Buddha image inside double round frame, SI 2019) as a binding hole decoration appears at first time in the manuscript from the southern Tarim oases. ${ }^{40}$ There are guidelines not only for lines but also for left margin designation (SI 3030). The pagination is located on recto strictly. The paper is laid; traces of primer are not always visible; the leaves surface is smooth, possibly polished. There is paper of high as well as low quality; there are fiber traces in paper pulp of the manuscripts SI 3030, SI 3330. There are manuscripts of absolutely different sizes: there are medium $(8 \times 35 \mathrm{~cm}$, SI 3037$)$ and small $(6 \times 18 \mathrm{~cm}$, SI $3332 / 1)$ manuscripts in addition to the large format pothī leaves. We can say that 5 th-6th cc. is the period of the beginning of the Southern Turkestan manuscript tradition.

The next stage of the development of the manuscript tradition in the southern Serindia oases is reflected in the manuscripts written in Early Southern Turkestan Brāhmī (7th-8th cc.) — such as Kāśyapaparivarta-sūtra (SI 1905, SI 2014), Saddharmapuṇụarīka-sūtra (SI 1941), Ratnarāśi-sūtra (SI 2013) and others. The paper of these manuscripts has characteristics similar to the manuscripts of the previous tradition: it's a laid, with a fiber fragments. The margins and the binding hole are not marked (except of the manuscript SI 1905 where the binding hole is marked by a circle and the left margin is outlined by guidelines). The pagination is located on the recto in all manuscripts. The manuscript SI 1905 has wooden covers. Most likely, the manuscripts with a large number of leaves had wooden covers for better preservation. The wooden cover has a binding hole. These covers are not decorated in any way additionally, the text traces can be found on the inside. The one more manuscript has a similar wooden covers (Saddharmapuṇụarika-sūtra, SI 1925). The manuscripts sizes are $6 \times 40 \mathrm{~cm}$ (SI 1905), $10 \times 26 \mathrm{~cm}$ (SI 1941) and $6 \times 28 \mathrm{~cm}($ SI 2013-2014).

The manuscripts written in Southern Turkestan Brāhmī are most numerous within 'Sanskrit division' of the Serindia Collection. Buddhanāma-sūtra

\footnotetext{
40 The manuscript SI 2016 has an empty double circle (obviously for a miniature also). There are no another miniatures (except of the colored Buddha image on the leaf of SI 2019) in the manuscripts written by this script type.
} 
(SI 2075-2076, SI 3015-3016, SI 3027), Ajitasenavyākaraṇa (SI 2085), Dharmaśarīra-sūtra (SI 2086, SI 3014), Samādhirāja-sūtra (SI 3001-3002), Sumukhanāma-dhāraṇī (SI 3026), Prajñāparamitā (SI 3682) as well as almost all versions of the Lotus Sutra that will be discussed below are excellent examples of this script type. ${ }^{41}$ The codicological features of these manuscripts are very similar: the binding hole is marked by a circle; the paper is laid, with an occasional fiber fragments; the pagination is located on recto only. Some manuscripts have guidelines (SI 3001-3002, SI 3015). The left margin is marked with guidelines very rare (SI 2085), the right margin is present sometimes but it hasn't graphical guidelines. The margins in the manuscripts are both wide $(2.5 \mathrm{~cm}$, SI 3002$)$ and narrow $(0.8 \mathrm{~cm}$, SI 3027$)$. The leaves have absolutely different sizes: there are manuscripts of both small $-4 \times 20 \mathrm{~cm}$ (SI 2086), and large $-20 \times 58 \mathrm{~cm}$ (SI 3682) formats. It's remarkable that the leaf size didn't determine the lines number. For example, manuscripts SI $3014(8 \times 37 \mathrm{~cm})$ and SI $3026(4 \times 25 \mathrm{~cm})$ contain the same number of lines: 4 lines on both sides of the leaf. In the first case, lines are located at a great distance from each other $(2.0 \mathrm{~cm})$, in the second - at a distance of $0.8 \mathrm{~cm}$.

As was mentioned above the manuscripts written in Southern scripts are most numerous in the Serindia Collection. In particular, all Saddharmapuṇarīka fragments are written in the scripts spread in the southern oases of Serindia. The main part of the Lotus Sutra fragments was written in Southern Turkestan Brāhmī as well as the Kashgar manuscript of Petrovskii that is the longest version of the sūtra (about 400 leaves) and the core of the Sanskrit manuscripts containing the Saddharmapundarinka text. The group of the Lotus Sutra manuscripts perhaps is one of the largest in the Serindia Collection (28 items). As a rule, these manuscripts belong to the Petrovskii Collection: SI 1925; SI 1927; SI 1933-1941; SI 2077; SI 2092; SI 2093; SI 2098; SI 3000; SI 3013; SI 3025; SI 3030; SI 3044; SI 3631; SI 3693; SI 3694. Four items (two ones in each collection) are presented in the collections of Mikhail I. Lavrov (SI 3330; SI 3332/3) and Sergei E. Malov (SI 4517; SI 4519). One more item belongs to the Sergei F. Oldenburg Collection (SI 4645). The codicological features of these manuscripts are similar to other fragments written in Southern Turkestan Brāhmī. The paper of good enough quality, the no primer traces are not visible. In some manuscripts, mainly in large and decorated ones

\footnotetext{
${ }^{41}$ Among all version of the Lotus Sūtra kept the Serindia Collection two only manuscripts (SI 1941, SI 3030, SI 3330; SI 3332/3) written in earlier script types; other Saddharmapundarīka manuscripts written in Southern Turkestan Brāhmī.
} 
(for example, SI 3025 size: $14 \times 54 \mathrm{~cm}$ ), margins are outlined and there are laid traces made by a lead stick. In addition, the manuscript SI 1933 has an image (Śākyamuni Buddha with a donator), and there is a double decorative circle for a miniature on some leaves of SI 1925 and SI 1927.

It's necessary to mention separately the Sanskrit manuscripts written in the so-called Gilgit-Bamiyan Brāhmī (type2; 6th c.). Manuscripts SI 2041/5 and SI 3695 are the fragments of the Kalpanāmaṇịtikā ("Decorated Poem") attributed to the Buddhist poet Kumāralāta. The two other fragments (SI 2998, fragment No. 5 and SI 5521) written in the same script are not identified. This Brāhmī script type has another name — proto-Śāradā — and, as the name suggests, it precedes the western version of the Gupta script - Sāradā that arose approx. the 8th c. The codicological features of the fragments SI 2041/5, SI 2998 and SI 3695: the paper is one-layered, laid, of very high quality, with perfectly shredded paper pulp. SI 5521, in contrast, has a two-layered paper, of poor quality, the ink is slightly blurry. It can indicate a poor quality of material or a poorly processed paper surface. The pagination occurs only in one fragment (2041/5) - on verso. The guidelines are not visible. Obviously, this manuscripts were compiled on the territory of modern Afghanistan and Pakistan but the circumstances of their acquisition and existence in the Serindia manuscript Collection remain unclear.

\section{Conclusions}

The first stage of the Buddhism institutionalization in Serindia (2th4th cc.) was marked by the intensive 'export' of Buddhist teaching, as a rule, Hinayāna (Sarvāstivāda), from the northern regions of India and Kashmir. It can be testified, first of all, by the repertoire of the discovered Sanskrit fragments and, secondly, by the not typical for Serindia manuscripts material palm leaves and birch bark. During this period, Buddhist Dhārạ̄ī are spread in Serindia. These spell texts contain besides of Buddhist deities the names of Vedic gods. It's very typical for the the religious syncretism of the Kușāna Empire.

The second stage - 4th-6th cc. — is characterized by the keeping of Sanskrit as the main language of Buddhist manuscript tradition and the change of the manuscripts material from birch bark and palm leaves to locally produced paper. Ideologically, a turn towards Mahāyāna Buddhism is outlined. Such Mahāyāna texts as Mahāparinirvāṇa-sūtra, Prajñāpāramitā-sūtra, 
Saddharmapuṇuarīka-sūtra (the fundamental text for East Asian Buddhism) appear. At the same time, the Dhāraṇī texts retain their popularity.

The peculiarity of the third stage — 6th-9th cc. — when both the Lotus Sūtra and another fundamental texts of Buddhist doctrine (Dharmaśarīrasūtra, Prātimokṣa-sūtra) as well as Dhāraṇ̄ remain their actuality, is an active appearance of the Buddhist texts in local languages (such as Khotanese Jñānolka-dhāraṇī) that marks the completion of the Buddhism institutionalization in Serindia.

In terms of codicology of the analyzed manuscripts it should be noted that, except of rare for Serindia the scroll manuscript format, poth $\bar{\imath}$ is a typical manuscript format for all Tarim oases regardless of the material. There were decorating changes that became more ornamental. Particularly, the margins and the area around a binding hole as well as guidelines needed for calligraphic writing started to be outlined. The pagination and features of leaves design began to vary depending on the region. It was in a same time (the middle of $1 \mathrm{st}$ millennium AD) when Brāhmī script was dividing into two separate scripts traditions - Northern and Southern. The earlier manuscripts were characterized by unstable pagination - the leaves could be paginated both on the recto and verso. Later, the recto pagination had become typical for the manuscripts from Southern Tarim oases but verso - for Northern ones. The outline of the area around a binding hole is another peculiarity of this stage: for Southern Tarim manuscripts it was a circle but for Northern ones - quadrangle. Moreover, Southern Tarim manuscripts had leaves with empty circles prepared for colored miniatures; two manuscripts have such images. The Northern Tarim manuscripts have neither decorated circles nor miniatures. The one more difference of the large deluxe manuscripts written in Southern Turkestan Brāhmī is the colorless guidelines in contrast of the Northern Turkestan Brāhmī manuscripts that guidelines are in black or red ink.

At present, the main goal of the Sanskrit group of the Laboratory Serindica is to compile the catalogue that would provide comprehensive codicological description of the Sanskrit manuscripts from the Serindia Collection. The group's tasks also include the research of Buddhism Sanskrit manuscripts in terms of their historical, cultural and source study value: the preliminary texts identification, general classification of the Central Asian Buddhist manuscript heritage and the clarification of its regionally specific features. In addition, the work on the compilation of an electronic dictionary of Buddhist texts from the Serindia Collection has recently begun. 


\section{Abbreviation}

ARIRIAB: Annual Report of the International Research Institute for Advanced Buddhology at Soka University

GRVL: Glavnaia redaktsiia vostochnoi literatury

MO: Manuscripta Orientalia

PPV: Pis'mennye Pamiatniki Vostoka [Written monuments of the Orient]

WMO: Written Monuments of the Orient

ZVORAO: Zapiski Vostochnogo Otdeleniia Imperatorskogo Russkogo Arkheologicheskogo Obshchestva [Proceedings of the Oriental Department of the Imperial Russian Archaeological Society]

\section{References}

Bongard-Levin, Grigorii M. 1972: "Dva novykh fragmenta "Saddkharmapundariki" (predvaritel'noe soobshchenie)" [The two new fragments of Saddharmapuṇaraika (preliminary report)]. Indiiskaia kul'tura i buddizm [The Indian culture and Buddhism]. Moscow: Nauka, GRVL: 187-191.

Bongard-Levin, Grigorii M. 1975a: "Sanskritskie rukopisi iz Tsentral'noi Azii (fragment makhaianskoi "Makhaparinirvanasutry")" [Sanskrit manuscripts from Central Asia (a fragment of the Mahāyāna Mahāparinirvāṇa sūtra)]. Vestnik drevnei istorii [Journal of Ancient History] 4. Moscow: Nauka: 75-79.

Bongard-Levin, Grigorii M. 1975b: “Novye indiiskie teksty iz Tsentral'noi Azii (neizvestnyi fragment makhaianskoi "Makhaparinirvany")" [New Indian texts from Central Asia (unknown fragment of the Mahāyāna Mahāparinirvāṇa sūtra)]. Narody Azii i Afriki [The peoples of Asia and Africa] 6: 145-151.

Bongard-Levin, Grigorii M. 1977: "Novyi fragment makhaianskoi "Makhaparinirvanasutry" [A new fragment of the Mahāyāna Mahāparinirvāṇa sūtra]. Acta Antiqua Academiae Scientiarum Hungaricae XXV: 243-248.

Bongard-Levin, Grigorii M. 1979: “Fragment sanskritskoi Samādhirājasūtra iz Tsentral'noi Azii" [A fragment of the Sanskrit Samādhirājasūtra from Central Asia.]. Sanskrit i drevneindiiskaia kul'tura [Sanskrit and ancient Indian culture] I. Moscow: Nauka: 62-72.

Bongard-Levin, Grigorii M. 1980: “A New Fragment of the Sanskrit Sumukhadhāran̄i and its Saka Version”. Indologica Taurinensia VIII-IX. Torino: Ed. Jollygrafica: 45-49.

Bongard-Levin, Grigorii M. 1981: "New Buddhist Sanskrit Texts from Central Asia: An Unknown fragment of the Mahāyāna Mahāparinirvānasūtra". The Journal of the International Association of Buddhist Studies 4/2: 7-16.

Bongard-Levin, Grigorii M. 1982: "New Indian Texts from Central Asia (a New Fragment of the Mahāyāna "Mahāparinirvāṇasūtra")". Indologica Taurinensia X. Torino: Ed. Jollygrafica: $55-64$.

Bongard-LeVIn, Grigorii M. 1989: "Three New Fragments of the Bodharājakumārasūtra from Eastern Turkestan". Journal of the American Oriental Society 109/4: 509-512.

Bongard-Levin, Grigorii M. 1994: "A Fragment of the Pañcavimiśatisāhasrikā Prajñāpāramitāsütra from Eastern Turkestan”. Journal of the American Oriental Society 114/3: 383-385. 
Bongard-Levin, Grigorii M. \& Boucher, Daniel \& Fukita, Takamichi \& Wille, Klaus 1996: The Nagaropamasūtra: An Apotropaic Text from the Samyuktāgama. A Transliteration, Reconstruction, and Translation of the Central Asian Sanskrit Manuscripts. Göttingen: Vandenhoeck \& Ruprecht (Sanskrit-Texte aus dem buddhistischen Kanon: Neuentdeckungen und Neueditionen III, Sanskrit-Wörterbuch der buddhistischen Texte aus den Turfan-Funden, Beiheft 6).

Bongard-Levin, Grigorii M. \& Hori, Shin'ichirō 1996: “A Fragment of the Larger Prajñāpāramitā from Central Asia". Journal of the International Association of Buddhist Studies 19/1: 19-60.

Bongard-Levin, Grigorii M. \& Kimura, Takayasu 1995: "New Fragments of the Pañcaviṃśatisāhasrikā Prajñāpāramitā from Eastern Turkestan". East and West 45, No. 1/4: 355-358.

Bongard-Levin, Grigorii M. \& Tiomkin, Eduard N. 1968: "Fragment neizvestnoi rukopisi "Saddkharmapundariki" iz kollektsii N.F. Petrovskogo" [Fragment of an unknown manuscript of the Saddharmapundarīka from the N.F. Petrovsky Collection]. Iazyki Indii, Pakistana, Nepala i Tseilona [Languages of India, Pakistan, Nepal and Ceylon]. Moscow: Nauka, GRVL: 439-451.

Bongard-Levin, Grigorii M. \& Vorobiova-Desiatovskaia, Margarita I. 1986: "Novyi tekst fragmenta sanskritskoi "Sumukkha-dkharani" [A new text from the fragment of the Sanskrit Sumukha-dhāraṇī]. Peredneaziatskii sbornik [Western Asian almanac] 4. Moscow: Nauka, GRVL: $156-159$.

Bongard-Levin, Grigorii M. \& Vorobiova-Desiatovskaia, Margarita I. 1987: "Novye sanskritskie teksty iz Tsentral'noi Azii" [New Sanskrit texts from Central Asia]. Tsentral'naia Aziia: Novye pamiatniki pis'mennosti i iskusstva [Central Asia: New Monuments of Writing and Art]. Moscow: Nauka. GRVL: 6-18.

Bongard-Levin, Grigorii M. \& Vorobiova-Desiatovskaia, Margarita I. \& Tiomkin Eduard N. 1967: “A Fragment of the Sanskrit Sumukhadhāraṇ̄". Indo-Iranian Journal 10/2-3: 150159.

Bongard-Levin, Grigorii M. \& Watanabe, Shōgo 1997: “A fragment of the Sanskrit text of the Sìlapāramitä’. Wiener Zeitschrift für die Kunde Südasiens und Archiv für indische Philosophie = Vienna journal of South Asian studies 41: 93-98.

Brockington, John 2010: "The Spitzer Manuscript and the Mahābhārata". From Turfan to Ajanta: Festschrift for Dietrich Schlingloff on the occasion of his eightieth birthday. Rupandehi: Lumbini International Research Institute: 75-87.

Durkin-Meisterernst, Desmond et al. 2016: "Scientific methods for philological scholarship: Pigment and paper analyses in the field of manuscriptology". Journal of Cultural Heritage 17: 7-13.

Franco, Eli 2004: The Spitzer Manuscript. The Oldest Philosophical Manuscript in Sanskrit. Vol. I, II. Wien: Verlag der Österreichischen Akademie der Wissenschaften.

HINÜBER, Oskar von 2015: "Three Saddharmapuṇ̦arīkasūtra Manuscripts from Khotan and Their Donors". ARIRIAB XVIII: 215-234.

HoERnLe, Rudolf 1902: A Report of the British Collection of Antiquities from Central Asia. Pt. 2. Calcutta: Baptist Mission Press. 
Hori, Shin'ichirō 堀伸一郎 2011: “Roshia Kagaku Akademī Tōyō Shahon Kenkyūjo shozō Chūō-Ajia shutsudo Sansukuritto dampen ni tsuite” ロシア科学アカデミー東洋写本 研究所所蔵中央アジア出土サンスクリット断片について [Sanskrit Fragments from Central Asia at the Institute of Oriental Manuscripts of the Russian Academy of Sciences, St. Petersburg]. Bukkyōgaku 仏教学 [Journal of Buddhist Studies] 53: 1-24.

Inventory No. 1 1930: The Archives of the Department of Manuscripts and Documents of the IOM, RAS. Access number - Apx. 60.

Karashima, Seishi \& Vorobiova-Desiatovskaia, Margarita I. 2007: "Some Buddhist Sanskrit Fragments from the Collection of the St. Petersburg Branch of the Institute of Oriental Studies of the Russian Academy of Sciences" (1). ARIRIAB X: 45-56, Plates 1-3.

Karashima, Seishi \& Vorobiova-Desiatovskaia, Margarita I. 2008: "Some Buddhist Sanskrit Fragments from the Collection of the Institute of Oriental Manuscripts in St. Petersburg” (2). ARIRIAB XI: 91-94, Plates 1-2.

Karashima, Seishi \& Vorobiova-Desiatovskaia, Margarita I. 2015: The St. Petersburg Sanskrit Fragments (StPSF). Vol. I. Tokyo: IOM, RAS; IRIAB, Soka University (Buddhist Manuscripts from Central Asia).

Kudo, Noriyuki \& Vorobiova-Desiatovskaia, Margarita I. 2007: “A Newly Identified Fragment of the Saddharmapundarịkasütra kept in the St. Petersburg Branch of the Institute of Oriental Studies". ARIRIAB X: 57-66.

Mironov, Nikolai D. 1909: "Iz rukopisnych materialov ekspedicii M.M. Berezovskago v Kuchu" [From the handwritten materials of the M.M. Berezovsky expedition to Kucha]. Bulletin de l'Académie des Sciences de St. Pétersbourg, VI série, 8: 547-562.

OL'DENBURG, Sergei F. 1893: "Otryvki kashgarskikh sanskritskikh rukopisei iz sobraniia N.F. Petrovskogo" [Fragments of the Kashgar Sanskrit manuscripts from the collection of N.F. Petrovsky] (1). ZVORAO VIII: 47-67.

Ol'DenBuRG, Sergei F. 1899: “Otryvki kashgarskikh i sanskritskikh rukopisei iz sobraniia N.F. Petrovskogo" [Fragments of the Kashgar Sanskrit manuscripts from the collection of N.F. Petrovsky] (2). ZVORAO XI: 207-265.

Ol'DENBURG, Sergei F. 1904: "Otryvki kashgarskikh sanskritskikh rukopisei iz sobraniia N.F. Petrovskogo" [Fragments of the Kashgar Sanskrit manuscripts from the collection of N.F. Petrovsky] (3). ZVORAO XV: 113-122.

Pamiatniki indiiskoi pis'mennosti 1985: Pamiatniki indiiskoi pis'mennosti iz Tsentral'noi Azii. Vyp. 1. Izdanie tekstov, issledovanie i kommentarii G.M. Bongard-Levina i M.I. VorobiovoiDesiatovskoi [Indian Texts from Central Asia. Vol. 1. Publication of texts, study and commentaries by G.M. Bongard-Levin and M.I. Vorobiova-Desiatovskaia]. Moscow: Nauka, GRVL.

Pamiatniki indiiskoi pis'mennosti 1990: Pamiatniki indiiskoi pis'mennosti iz Tsentral'noi Azii. Vyp. 2. Izdanie tekstov, issledovanie, perevod i kommentarii G.M. Bongard-Levina i M.I. Vorobiovoi-Desiatovskoi [Indian Texts from Central Asia. Vol. 2. Publication of texts, study, translation, and commentaries by G.M. Bongard-Levin and M.I. Vorobiova-Desiatovskaia]. Moscow: Nauka, GRVL.

Pamiatniki indiiskoi pis'mennosti 2004: Pamiatniki indiiskoi pis'mennosti iz Tsentral'noi Azii. Vyp. 3. Izdanie tekstov, issledovanie, perevod i kommentarii G.M. Bongard-Levina, M.I. Vorobiovoi-Desiatovskoi, E.N. Tiomkina [Indian Texts from Central Asia. Vol. 3. Publi- 
cation of texts, study, translation, and commentaries by G.M. Bongard-Levin, M.I. Vorobiova-Desiatovskaia, E.N. Tiomkin]. Moscow: Vostochnaia literatura.

Peshchery tysiachi budd 2008: Peshchery tysiachi budd: Rossiiskie ekspeditsii na Shelkovom puti. K 190-letiiu Aziatskogo muzeia. Katalog vystavki [The Caves of One Thousand Buddhas. Russian expeditions on the Silk Route. On the occasion of 190 years of the Asiatic Museum. Exhibition Catalogue]. St. Petersburg: The State Hermitage Publishers.

SANDER, Lora 2005: Remarks on the Formal Brāhmī Script from the Southern Silk Route. Bulletin of the Asia Institute, New Series 19: 133-144.

SHomakHMadov, Safarali H. 2014: "Ksilografy pis'mom siddham iz kollektsii IVR RAN" [Xylographs in the Siddham Script at the IOM Collection]. PPV 2(21): 212-221.

Shomakhmadov, Safarali H. 2016: "Issledovaniie S.F. Ol'denburgom kashgarskih sanskritskikh rukopisei iz sobraniia N. F. Petrovskogo" [The S.F. Oldenburg research of Kashgar Sanskrit Manuscripts from the N.F. Petrovsky Collection]. Sergei Fedorovich Ol'denburg - uchenyi i organizator nauki [Sergei Fedorovich Ol'denburg — the scholar and the organizer of science]. Moscow: Nauka, Vostochnaia literature: 428-449.

Shomakhmadov, Safarali H. 2016: "Sbornik zaklinanii-dkharani iz Khara-Khoto v Serindiiskom fonde IVR RAN. Predislovie, transliteratsiia, primechaniia S.Kh. Shomakhmadova" [Dhāranī Invocations from Khara-Khoto in the Serindia Manuscript Collection of IOM, RAS. Introduction, transliteration, notes by S.H. Shomakhmadov]. PPV 1(24): 5-24.

Shomakhmadov, Safarali H. 2017: "Dkharani-samuchchaia SI 6564 iz Khara-Khoto v rukopisnoi kollektsii IVR RAN. Predislovie, transliteratsiia i primechaniia S.Kh. Shomakhmadova" [Dhāranīi-samuccaya SI 6564 from Khara-Khoto in the Manuscripts Collection of IOM, RAS. Introduction, Transliteration and Notes by Safarali H. Shomakhmadov]. PPV 1(28): 5-14.

StaËL-Holstein, A. von 1926: The Kāçyapaparivarta: a Mahāyānasütra of the Ratnakūța Class. Edited in the original Sanskrit in Tibetan and in Chinese by Baron A. von StaëlHolstein = Da bao ji jing jia ye pin Fan Zang Han liu zhong he kan 大寶積經迦葉品 梵藏漢六種合刊 / Ganghetai zhu 鋼和泰著. Shanghai: Shang wu yin shu guan 商務印書 館.

TodA, Hirofumi 1981: Saddharmapundarīkasūtra: Central Asian manuscripts. Romanized text. Tokushima: Kyoiku Shuppan Center.

Tiomkin, Eduard N. 1995a: "Unique Sanskrit Fragments of the "Sutra of Golden Light" in the manuscript collection of St. Petersburg Branch of the Institute of Oriental Studies, Russian Academy of Sciences". MO 1/1: 29-38.

Tiomkin, Eduard N. 1995b: "Fragments of the "Saddharmapundarikka-sūtra" in the I.P. Lavrov manuscript collection of the St. Petersburg Branch of the Institute of Oriental Studies". MO 1/2: 9-15.

Tiomkin, Eduard N. 1996: "Unknown Sanskrit Fragments from Central Asia”. MO 2/4: 3-22.

Vorobiov-DesiatovskiI, Vladimir S. 1957: "Vnov' naidennye listy rukopisi Kāshiapaparivarty” [The newly found manuscript folios of Kāśyapaparivarta sūtra]. Rocznik Orientalistyczny XXI: 491-500.

Vorobiov-DesiatovskiI, Vladimir S. 1958: "Pamiatniki tsentral'noaziatskoi pis'mennosti" [Monuments of the Central Asian writing]. Uchenye zapiski Instituta vostokovedeniia [Memoirs of the Institute of Oriental studies] XVI: 280-308. 
Vorobiova-DesiatovskaiA, Margarita I. 1988a: "Rukopisnaia kniga v kul'ture Indii" [The ms. book in the culture of India]. Rukopisnaia kniga $v$ kulture narodov Vostoka [The ms. book in Oriental cultures] 2. Moscow: Nauka, GRVL.

Vorobiova-Desiatovskaia, Margarita I. 1988b: "Rukopisnaia kniga v kul'ture Tsentral'noi Azii $\mathrm{v}$ domusul'manskii period" [The ms. book in the culture of Central Asia in pre-Islamic period]. Rukopisnaia kniga v kul'ture narodov Vostoka [The ms. book in Oriental cultures] 2. Moscow: Nauka, GRVL.

Vorobiova-Desiatovskaia, Margarita I. 2004: "K istorii slozheniia buddiiskogo kanona: problema iazikovogo raznoobraziia i avtorstva buddiiskih kanonicheskih tekstov" [Regarding the History of Buddhist Canon: The Problem of the Language Variety and the Authorship]. PPV 1(1): 200-218.

Vorobiova-Desiatovskaia, Margarita I. 2011: "Materiali N.F. Petrovskogo v IVR RAN" [Materials of Nikolay F. Petrovsky at the Institute of Oriental Manuscripts of the RAS]. PPV 1(14): 184-196.

Vorobiova-Desiatovskaia, Margarita I. 2012: "Sanskritskaia Tripitaka v svete paleograficheskikh issledovanii 1920-2000-kh gg." [Sanskrit Tripitaka in the light of paleographical studies (1920-2000)]. In: Piatye vostokovednye chteniia pamiati O.O. Rozenberga [The 5th Oriental Readings in Memory of O.O. Rosenberg]. St. Petersburg: Izdatel'stvo A. Goloda: 78-96.

Vorobiova-Desiatovskaia, Margarita I. \& Shomakhmadov, Safarali H. 2010: "Problema issledovaniia neatributirovannoi avadani iz kollektsii IVR RAN" [The Problem of Interpretation of an Unknown Avadana from the Collection of the Institute of Oriental Manuscripts, RAS]. PPV 2(13): 64-72.

Vorobiova-Desiatovskaia, Margarita I. \& Shomakhmadov, Safarali H. 2011: "Khotanskaia versiia Adzhitasena-v'iakarana-nirdesha-nama-mahaiana-sutri iz kollektsii IVR RAN" [The Khotanese version of the Ajitasena-vyākaraṇa-nirdeśa-nāma-mahāyana-sūtra from the IOM, RAS collection]. PPV 1(14): 26-41.

Vorobiova-Desiatovskaia, Margarita I. \& Shomakhmadov, Safarali H. 2013: "Sutra Makhaiany, imenuemaia "Nastavlenie [kasatel'no] predskazaniia, [dannogo tsariu] Adzhitasene”" [The Mahāyāna Sutra Named "The Teaching [Concerning] the Prophecy [Given to Rāja] Ajitasena"]. PPV 1(18)]: 39-50.

Vorobiova-Desiatovskaia, Margarita I. 1995c: "The S.E. Malov Collection of Manuscripts in the St. Petersburg Branch of the Institute of Oriental Studies". MO 1/2: 29-39.

Vorobiova-Desiatovskaia, Margarita I. 1999-2002: "A Sanskrit Manuscript on Birch-Bark from Bairam-Ali: II. Avadānas and Jātakas”. $M O$ 6/3: $23-32$ (part 1); $M O$ 7/1: 10-23 (part 2); $M O$ 7/2: 10-19 (part 3); $M O$ 7/3: 9-14 (part 4); $M O$ 7/4: 12-21 (part 5); $M O$ 8/1: 18-26 (part 6); $M O$ 8/2: 20-28 (part 7); $M O$ 8/3: 26-33 (part 8).

Vorobiova-Desiatovskaia Margarita I. \& Karashima, Seishi \& Kudo, Noriyuki 2002: The Kāśyapaparivarta. Romanized Text and Facsimiles. Tokyo: IRIAB, Soka University.

Vorobiova-Desyatovskaya Margarita I. \& Tiomkin, Eduard N. 1998: "Fragments of Sanskrit Manuscripts on Birch-Bark from Kucha". MO 4/4: 21-26.

Vorobiova-Desiatovskaia, Margarita I. \& Tiomkin, Eduard N. 2000: “A Fragment of the Prātimoksha-sūtra from the I.P. Lavrov Collection at the St. Petersburg Branch of the Institute of Oriental Studies". MO 6/4: 24-29. 
Vostochnyi Turkestan 1992: Vostochnyi Turkestan v drevnosti i rannem srednevekov'e: Etnos, iazyki, religii [East Turkestan in Antiquity and the Early Middle Ages: Ethnos, Languages, Religions]. Moscow: Nauka, GRVL.

Wille, Klaus 1997: "New fragments of the Buddhadharmasutra". Indologica Taurinensia XXIII-XXIV: 363-386. 